\title{
Classic acrodermatitis enteropathica associated with cerebral atrophy in a term breastfed infant
}

\author{
*M B K C Dayasiri ${ }^{1}$, S Krishnapradeep ${ }^{2}$, K M T R Seneviratne ${ }^{3}$, R M Mudiyanse M C K Abeysekara $^{5}$ \\ Sri Lanka Journal of Child Health, 2016; 45(2):139-142 \\ DOI: http://dx.doi.org/10.4038/sljch.v45i2.8097 \\ (Key words: Acrodermatitis enteropathica, cerebral atrophy)
}

\section{Introduction}

Acrodermatitis enteropathica (AE), an autosomal recessive disorder caused by an inability to absorb sufficient zinc from diet, has an estimated incidence of 1 per 500,000 children, without a predilection for sex or race $^{1}$. AE is characterized by chronic diarrhoea, dermatitis and failure to thrive ${ }^{1}$. The gene SLC 39A4 that codes for intestinal zinc specific transporter is defective in $\mathrm{AE}^{2}$. Although the first symptoms usually develop within days after birth in bottle-fed infants, or after weaning from breast milk in older infants, AE can rarely manifest in infants who are exclusively breast $\mathrm{fed}^{3}$. We report a seven month old girl who presented with classic clinical and biochemical features of AE that was successfully managed with oral zinc and who had associated frontal lobe atrophy.

\section{Case report}

A seven month old girl, born to healthy second degree consanguineous parents, presented with a history of chronic diarrhoea since birth associated with growth failure and global developmental delay. She had developed symmetrically distributed, erythematous, scaly, erosive, and crusty plaques in perioral, perineal and buttock regions (Figures 1-3) since two months of age. Similar lesions were also noticed over cheeks, knees and elbows.

\footnotetext{
${ }^{1}$ Registrar, ${ }^{2}$ Senior Registrar, ${ }^{3}$ Intern House Officer, ${ }^{4}$ Senior Lecturer, ${ }^{5}$ Professor, University Paediatrics Unit, Teaching Hospital Peradeniya, Sri Lanka.

*Correspondence: mbkcdayasiri@gmail.com (Received on 06 March 2015: Accepted after revision on 27 April 2015)

The authors declare that there are no conflicts of interest

Personal funding was used for this project.

Open Access Article published under the Creative

Commons Attribution CC-BY (cC) (P)
}

Her birth weight was $3550 \mathrm{~g}$ (median). Since birth she passed around 10-12 loose watery stools each day. There was no history of explosive or foul smelling stools. She developed head nodding and hand tremors since five months. Her developmental milestones were compatible with three months and she had one episode of generalized convulsions at four months of age. Child was exclusively beast fed up to six months and complementary feeding was appropriately commenced.

Physical examination found growth faltering, glossitis, stomatitis, thin, sparse scalp hair and poorly developed eyebrows and eyelashes in addition to characteristic distribution of the skin rash. There were no abnormal urine odours, seborrheic dermatitis like skin rashes, acidotic breathing, hepatomegaly, and body oedema.

Serum zinc level was $21 \mu \mathrm{g} / \mathrm{dl}$ (normal range 70-150 $\mu \mathrm{g} / \mathrm{dl})$ with a marginally low alkaline phosphatase level (119 U/L). Liver and renal profiles and inflammatory markers (ESR $30 \mathrm{~mm} 1^{\text {st }}$ hour, CRP 4 $\mathrm{mg} / \mathrm{L})$ were normal. Arterial blood gases did not show any metabolic acidosis and anion gap was normal (11). Urine ketone bodies were negative. Abdominal ultrasound did not show any hepatomegaly. Stools full report was negative for fatty acids, lactose, worm cysts and giardia infection. Blood picture showed hypochromic microcytic anaemia with hypersegmented neutrophils and supplemental iron, folate and parenteral vitamin B 12 were subsequently prescribed. Serum TSH was 0.7 micro IU/ml (normal range 0.73-8.5 micro $\mathrm{IU} / \mathrm{ml}$ ). Electroencephalogram showed abnormal frontal focal spikes suggesting a structural abnormality and brain ultrasound showed frontal lobe atrophy. Magnetic Resonance Imaging (MRI) confirmed frontal lobe cerebral atrophy (Figure 4). Child was treated with oral zinc (50 mg daily) for one month and it dramatically relieved chronic diarrhoea and skin lesions with satisfactory weight gain (Figures 5-7). MRI brain studies were planned to further evaluate the progression of frontal lobe atrophy. 


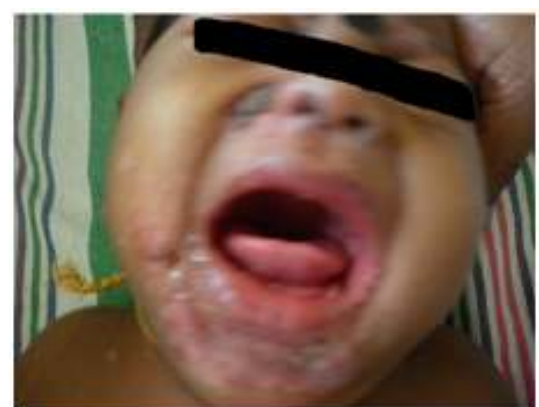

Figure 1: Perioral erythematous plaques

*Permission given by parents to publish photograph

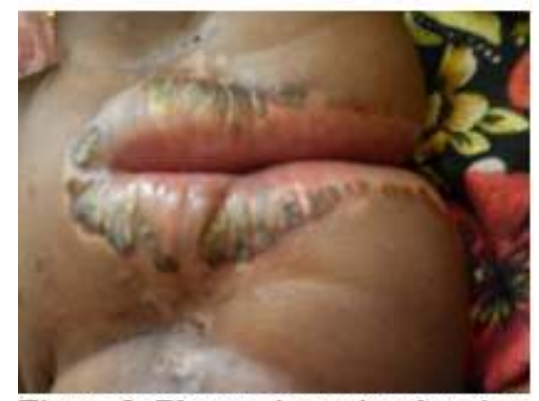

Figure 2: Plaques in perineal region

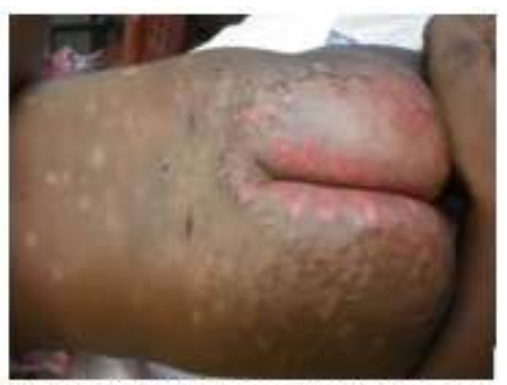

Figure 3: Plaques over buttocks

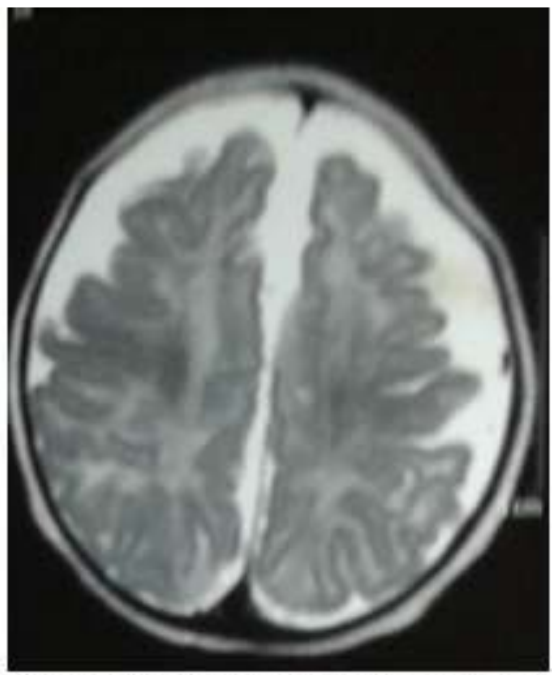

Figure 4: MRI showing predominant frontal lobe atrophy

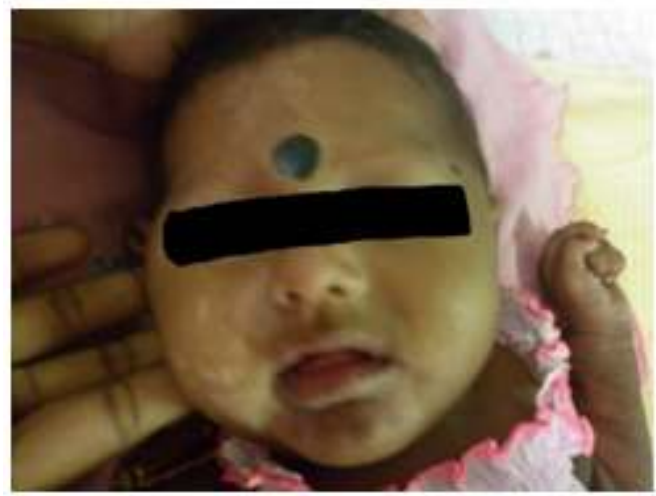

Figure 5: Healing skin lesions over face one month post-treatment

*Permission given by parents to publish photograph

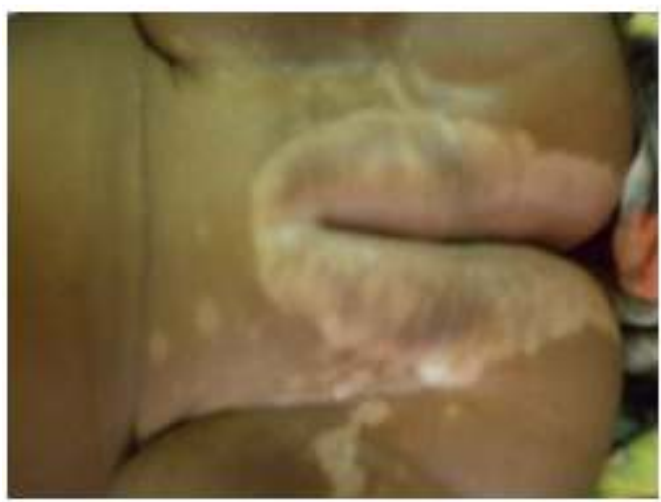

Figure 6: Healing skin lesions over perineum one month post-treatment

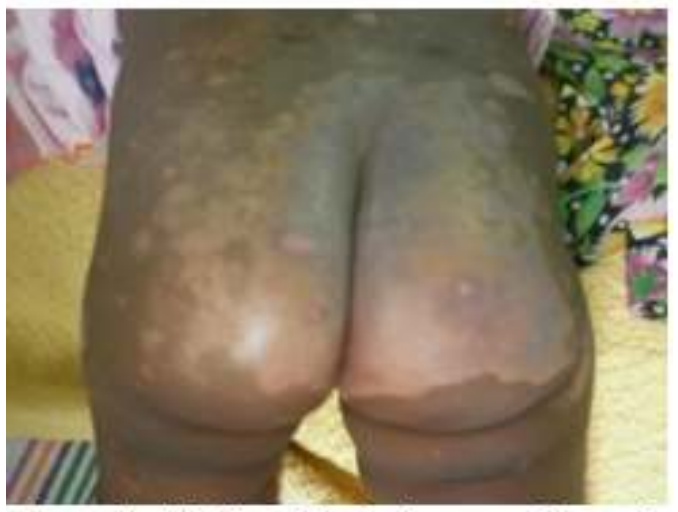

Figure 7: Healing skin lesions over buttocks one month post-treatment

\section{Discussion}

$\mathrm{AE}$ can be classified into two types: classic $\mathrm{AE}$ with a low serum zinc level and a variant with a normal serum zinc level ${ }^{4}$. In cases diagnosed as $\mathrm{AE}$, approximately $30 \%$ have a normal or higher serum zinc level ${ }^{5}$. This child had classic AE. Parental consanguinity supports autosomal recessive inheritance. 
Zinc deficiency can produce neuronal damage through increased free radical formation ${ }^{6}$ and adversely affect neurodevelopmental outcomes in children. Further, severe zinc deficiency can trigger apoptosis of neuronal cells in the brain ${ }^{7}$ leading to brain atrophy. If zinc deficiency is severe from early gestation, overt fetal brain malformations could occur $^{8}$. In this background, recent randomized controlled studies have clearly indicated that supplementation of zinc supports normative neurodevelopment ${ }^{9}$. For these reasons, the finding of frontal lobe atrophy and global developmental delay in this child with AE is noteworthy. Ohlsson (1981) described a Saudi boy who, despite being well fed, developed acrodermatitis enteropathica associated with cerebral cortical atrophy. The atrophy was shown to improve with oral zinc ${ }^{10}$. It would be interesting to see if this child too will benefit from oral zinc in overcoming developmental problems with time.

A low plasma zinc level is considered the gold standard for diagnosing zinc deficiency in $\mathrm{AE}^{11}$. Serum alkaline phosphatase, a zinc dependent enzyme, is another useful indicator of zinc status, as it may be low even when plasma zinc levels are low normal. Serum alkaline phosphatase can be used as a marker of therapeutic response for zinc supplementation, thus confirming the diagnosis of AE. If untreated, the disease is fatal. Patients with AE require lifelong treatment with zinc ${ }^{12}$.

This case highlights the importance of early diagnosis and initiation of treatment with oral zinc to reduce mortality and prevent long term consequences of zinc deficiency.

\section{References}

1. Maverakis E, Fung MA, Lynch PJ, et al. Acrodermatitis enteropathica and an overview of zinc metabolism. Journal of the American Academy of Dermatology 2007; 56: 116-24. http://dx.doi.org/10.1016/j.jaad.2006.08.015 PMid: 17190629

2. Kury S, Dreno B, Bezieau S, Giraudet S, Kharfi M, Kamoun R, et al. Identification of SLC39A4, a gene involved in acrodermatitis enteropathica. Nature Genetics 2002; 31: 239-40. http://dx.doi.org/10.1038/ng913

PMid: 12068297
3. Roberts LJ, Constance FS, Bergstresser PR. Zinc deficiency in two full-term breast-fed infants. Journal of the American Academy of Dermatology 1987; 16: 301-4. http://dx.doi.org/10.1016/S01909622(87)70 039-5

4. Aggett PJ. Acrodermatitis enteropathica. Journal of Inherited Metabolic Disease 1983; 6 (Suppl. 1):39-43. http://dx.doi.org/10.1007/BF01811322 PMid: 6413773

5. Mack D, Koletzko B, Cunnane S, Cutz E, Griffiths A. Acrodermatitis enteropathica with normal serum zinc levels: diagnostic value of small bowel biopsy and essential fatty acid determination. Gut1989; 30:14269. http://dx.doi.org/10.1136/gut.30.10.1426 PMid: 2638577 PMCid: PMC1434411

6. Menzano $\mathrm{E}^{1}$, Carlen PL. Zinc deficiency and corticosteroids in the pathogenesis of alcoholic brain dysfunction--a review. Alcohol Clin Exp Res. 1994; 18(4):895-901. http://dx.doi.org/10.1111/j.15300277.1994.t b00057.x

7. Clegg MS, Hanna LA, Niles BJ, Momma TY, Keen CL. Zinc deficiency-induced cell death. IUBMB Life 2005; 57(10):661-9. http://dx.doi.org/10.1080/152165405002645 54

PMid: 16223705

8. Adamo AM, Oteiza PI. Zinc deficiency and neurodevelopment: the case of neurons. Biofactors 2010; 36(2):117-24. http://dx.doi.org/10.1002/biof.91

9. Colombo J, Zavaleta N, Kannass KN, Lazarte F, Albornoz C, Kapa LL, et al. Zinc supplementation sustained normative neurodevelopment in a randomized, controlled trial of Peruvian infants aged 6-18 months. Journal of Nutrition 2014; 144(8):1298-305. http://dx.doi.org/10.3945/jn.113.189365 PMid: 24850625 PMCid: PMC4093986 
10. Ohlsson, A. Acrodermatitis enteropathica: reversibility of cerebral atrophy with zinc therapy. Acta Paediat. Scand. 1981; 70: 269-73.

http://dx.doi.org/10.1111/j.16512227.1981.t b05556.x

PMid: 7234413
11. Shakya NB, Rajbhandari SL, Jha SM. Acrodermatitis enteropathica: a case report. Medical Journal of Shree Birendra Hospital 2011: 10(2) 32-4.

12. Odom RB, James WB, Berger TG. Andrews Disease of the skin, Clinical dermatology, 9th edition. 2000; 484. 